\title{
ECOTOXICOLOGICAL EVALUATION THE EFFECTS OF THE SAFE CONCENTRATION OF WASTEWATER CONTAINING PHENOL ON AQUATIC ECOSYSTEMS
}

\author{
Olena BEZVERBNA ${ }^{1^{*}}$, Monika ZAŁĘSKA-RADZIWIŁŁ ${ }^{2}$ \\ ${ }^{1}$ Department of Ecology, Education and Research Institute of Ecological Safety, National Aviation University, \\ 1 Kosmonavta Komarova ave, 03680 Kyiv, Ukraine \\ ${ }^{2}$ Department of Biology, Faculty of Building Services, Hydro and Environmental Engineering, Warsaw University \\ of Technology. 20 Nowowiejska str., 00-653 Warsaw, Poland
}

Received 11 November 2016; accepted 22 June 2017

\begin{abstract}
The aim of this study was to identify the toxicity, determine and verify safe concentration of effluents containing phenol to the aquatic ecosystems on the basis of single- and multispecies ecotoxicological bioassays. Synthetic wastewater imitating municipal sewage showed acute toxicity in relation to all bioindicators and belonged to the third toxicity class. The most sensible organism was Danio rerio, the most resistance organism was Desmodesmus quadricauda. Chronic safe concentration of wastewater containing phenol was $0.63 \%$ which corresponded to $0.63 \mathrm{mg} / \mathrm{l}$ of phenol. Appointed safe concentration and the one ten times higher than safe were verified in microcosm study, which confirmed that safe concentration did not cause toxic effects. Maximum permissible concentration of phenol in water bodies does not exceed determined concentration in different countries. Proposed research model can be used to determine and verify safe concentrations for aquatic ecosystems of many types of sewage from various industries.
\end{abstract}

Keywords: phenol, wastewater, toxicity, safe concentration, bioassay, microcosm, water bodies, water pollution.

\section{Introduction}

The problem of phenolic water pollution is actual from the second half of the XX century until now in Ukraine and abroad. Phenol is one of the most common pollutants that enter surface water with untreated or insufficiently treated domestic sewage and industrial effluents of oil refining, woodworking, by-product-coking, wood-pulp, paper, plastic, resin and textile industrial enterprises (Michalowicz, Duda 2007).

Concentrations of phenol up to 10 times higher than maximum permissible are observed in numerous Ukrainian water bodies such as Dnieper river and its tributaries Gorin, Desna, Sula, Grouse, Vorskla, Samara, Ingulets which receive industrial wastewater. Nowadays, in conditions of mass urbanization, special risk is arising from the use of contaminated water bodies of urban agglomerations for recreational purposes. This is intensified by additional income of phenol in the issue of summer natural processes. For example, in Lake Vyrlytsia (Kyiv, Ukraine) which partly used for recreational purposes, the content of phenols coming mainly from the industrial zone from time to time exceed maximum permissible concentration in 5 times.

Phenol toxicity relates to two main processes - unspecified toxicity related to hydrophobocity of the individual compound and formation of free radicals. Ability of phenol and its derivatives to alter membrane structure leads to the imbalance of cell environment which results in the cells' death (Hansch et al. 2000). Phenol exposure causes the disruption of metabolic system in microorganism, animal and human. It can strongly inhibit the growth of bacteria, algae and mollusks (Gao et al. 2006; Huang et al. 1996; Park et al. 2012). After entering into the fish body, phenol compounds affect the metabolism, survival, growth and reproductive potential of fish (Nahed S. Gad, Amal S. Saad 2008; Hori et al. 2006). There are various median lethal concentration $\mathrm{LC}_{50}$ of phenol for different fish species. For example, for Ictalurus punctatus and Piaractus mesopotamicus $\mathrm{LC}_{50}$ values are 15.08 and $32.56 \mathrm{mg} / \mathrm{l}$ respectively (Moraes et al. 2015),

*Corresponding author. E-mail: elena.chumanova@gmail.com 
for Oreochromis mossambicus it is $28.49 \mathrm{mg} / \mathrm{L}$ (Saha et al. 1999), for Clarius lazera it is $150 \mathrm{mg} / \mathrm{L}$ (Zaki et al. 2011). With regard to human health, phenol damages kidneys, liver, muscle, eyes; it irritates skin and causes its necrosis (Bazrafshan et al. 2013).

The aim of this study was to determine the safe concentration of effluents containing phenol to the aquatic ecosystems.

\section{Previous research on the subject}

While there not many studies have been done on toxicity evaluation of wastewater containing phenol, quite a number of ecotoxicological researches were carried out to assess phenol toxicity to different test objects. Among other authors' study of phenol toxicity, there were ones conducted by Załęska-Radziwiłł M., Sheedy B. R., Lazorchak J. M., Grunwald D. J., Pickering Q. H., Pilli A., Hall D., Weeb R., Kaiser K. L., Palabrica V. S. In their researches median lethal concentration $\mathrm{LC}_{50}$ and median effective concentration $\mathrm{EC}_{50}$ values were obtained for algae Selenastrum capricornutum in the range from $224 \mathrm{mg} / \mathrm{l}$ to $150 \mathrm{mg} / \mathrm{l}$, Chlorella vulgaris - from $370 \mathrm{mg} / \mathrm{l}$ to $63 \mathrm{mg} / \mathrm{l}$, rotifer Brachionus calyciflorus - from $1200 \mathrm{mg} / \mathrm{l}$ to $42 \mathrm{mg} / \mathrm{l}$, crustacean Daphnia magna - from $78 \mathrm{mg} / \mathrm{l}$ to $10 \mathrm{mg} / \mathrm{l}$, crustacean Thamnocephalus platyurus - from $75.5 \mathrm{mg} / \mathrm{l}$ to $33 \mathrm{mg} / \mathrm{l}$, crustacean Artemia salina - from $260 \mathrm{mg} / \mathrm{l}$ to $175 \mathrm{mg} / \mathrm{l}$, bacteria Vibrio fischeri - from $42 \mathrm{mg} / \mathrm{l}$ to $21.1 \mathrm{mg} / \mathrm{l}$ (Załęska-Radziwiłł 1997; Sheedy et al. 1991; Kaiser, Palabrica 1991; Provisional List 1993).

Toxicity of wastewater from a resin production plant containing phenol to aquatic organisms from different taxonomic groups was studied by Tatjana Tisler and Jana Zagorc-Koncan. Test organisms included mixed bacterial culture, algae Scenedesmus quadricauda, crustacean Dophnia pulex and fish Oncorhynchus mykiss. Toxicity assessment was based on estimation of $\mathrm{LC}_{50}$ and $\mathrm{EC}_{50}$. It was found out that $\mathrm{EC}_{35}$ of effluents with concentration of phenol $70 \mathrm{mg} / \mathrm{l}$ was $100 \%$ for mixed bacterial culture, $\mathrm{EC}_{50}$ of wastewater with concentration of phenol $40.3 \mathrm{mg} / \mathrm{l}$ was $57.5 \%$ for Scenedesmus quadricauda, $\mathrm{EC}_{50}$ of effluents with concentration of phenol $12 \mathrm{mg} / \mathrm{l}$ was $17.2 \%$ for Daphnia pulex, $\mathrm{LC}_{50}$ of wastewater with concentration of phenol $12.9 \mathrm{mg} / \mathrm{l}$ was $18.5 \%$ for Oncorhynchus mykiss (Tisler, Zagorc-Koncan 1997). Operation with LC and EC values is suitable for comparison of toxicity but it is not enough for applying to the environment. For decisionmaking, we should operate with other indicators, such as safe concentration.

\section{Scope of the research}

The scope of the research included conducting of the following single-species bioassays with representatives of different trophic levels on wastewater containing phenol: algal growth inhibition test with Desmodesmus quadricauda, immobilization toxicity test with crustacean Daphnia magna Straus, fish Lebistes reticulatus Peters and Danio rerio, enzymatic tests with Daphnia magna Straus and bacteria Vibrio fischeri. On the basis of bioassaying results, chronic safe concentrations of studied wastewater were identified. Appointed safe chronic concentration was verified in the aquatic ecosystem model of microcosm type.

\section{Materials and methods}

\subsection{Materials}

In the research, there was used synthetic wastewater prepared in laboratory by Weinberger method (Weinberger 1949). Such type of wastewater is representative and universal as it imitates municipal sewage - the composition of domestic wastewater, industrial wastewater and stormwater.

It is comprised of the following ingredients: dry nutrient medium $\left(75 \mathrm{mg} / \mathrm{dm}^{3}\right)$, peptone $\left(50 \mathrm{mg} / \mathrm{dm}^{3}\right)$, urea $\left(30 \mathrm{mg} / \mathrm{dm}^{3}\right)$, sodium acetate $\left(100 \mathrm{mg} / \mathrm{dm}^{3}\right)$, sodium chloride $\left(30 \mathrm{mg} / \mathrm{m}^{3}\right)$, potassium chloride $\left(7 \mathrm{mg} / \mathrm{dm}^{3}\right)$, calcium chloride $\left(7 \mathrm{mg} / \mathrm{dm}^{3}\right)$, magnesium sulfate $(50 \mathrm{mg}$ / $\left.\mathrm{dm}^{3}\right)$, hydro sodium phosphate $\left(63 \mathrm{mg} / \mathrm{dm}^{3}\right)$, sodium bicarbonate $\left(168 \mathrm{mg} / \mathrm{m}^{3}\right)$, soluble starch $\left(100 \mathrm{mg} / \mathrm{dm}^{3}\right)$, and distilled water. Phenol concentration in the studied wastewater was $100 \mathrm{mg} / \mathrm{l}$.

\subsection{Toxicity bioassays}

\subsubsection{Producers}

Growth inhibition test with Desmodesmus quadricauda was conducted in accordance with ISO 8692 Standard (2012). Algae in exponential growth phase were added to the mineral medium containing defined concentrations of wastewater. Test consisted of calculation of algae cells number in $1 \mathrm{ml}$ of sample using a microscope before and after 72-hour exposure time and estimation of algae growth-rate reduction by $50 \%\left(\mathrm{EC}_{50}-72 \mathrm{~h}\right)$.

\subsubsection{Consumers}

One-hour $\mathrm{EC}_{50}$ value was calculated as a result of the acute enzymatic test with Daphnia magna Straus (Janssen et al. 1993). Toxicity evaluation was based on inhibition of galactosidase enzyme activity and as a consequence inhibition of light emission by irreversibly damaged organisms under UV light.

Acute toxicity tests with Daphnia magna, Lebistes reticulatus Peters and Danio rerio were conducted in accordance with ISO 6341 Standard (2012) and Polish Standard PN-90/C-04610.04 (1990). Organisms were exposed to different concentrations of wastewater for a certain time. Test was based on estimation of organisms' immobilization and survival after $48 \mathrm{~h}$ for crustacean and $96 \mathrm{~h}$ for fishes. Data are represented as $\mathrm{LC}_{50}$.

\subsubsection{Decomposers}

The LUMIStox acute toxicity test with bacteria Vibrio fischeri was carried out using LUMIStox measuring instrument model 1.07 in accordance with methodology 
included in the implementing instruction (LUMIStox 1994). Test was based on inhibition of the luciferase enzyme and as a consequence reduction of bacteria light emission intensity. The assessment of the bioluminescence inhibition was conducted after 30 min of bacteria exposure to different concentrations of wastewater.

\subsection{Calculation methods}

The percentage of algae growth rate inhibition $I \mu_{i}$ was calculated by the formula

$$
I_{i}=\frac{\mu_{c}-\mu_{i}}{\mu_{c}} \times 100 \%,
$$

where $\mu_{c}$ - average growth rate of algae in the control sample, $\mu_{i}$ - average growth rate of algae in the given concentration that was determined from the obtained number of algae cells in $1 \mathrm{~cm}^{3}$ at time $t_{0}\left(N_{0}\right)$ and the number of algae cells in $1 \mathrm{~cm}^{3}$ at time $t\left(N_{n}\right)$, using equation:

$$
\mu_{i}=\frac{\ln N_{n}-\ln N_{0}}{t_{n}} .
$$

For all conducted bioassays, except LUMIStox test, lethal and effective concentrations LC(EC) ${ }_{50}$ were determined by probit analysis with $95 \%$ confidence intervals (Weber 1972). LUMISsoft II software was used for obtaining $\mathrm{EC}_{50}$ during 30 min of exposure time for test with bacteria Vibrio fischeri.

For NOEC (No Observed Effect Concentration) calculation was done extrapolation from the results of acute toxicity using Acute to Chronic Ratio $A C R=10$ according to the formula

$$
N O E C=\frac{L C(E C)_{50}}{A C R} .
$$

Acute toxicity units $T U_{a}$ were obtained from the equation:

$$
T U_{a}=\frac{100}{L C(E C)_{50}} .
$$

Chronic toxicity units $T U_{c}$ were determined in accordance with formula

$$
T U_{c}=\frac{100}{N O E C} .
$$

Estimation of safe concentration $(S C)$ with regard to the chronic toxicity is based on the assumption that it does not exceed CCC - Criteria Continuous Concentration the highest concentration that does not cause toxic effects in zone of mixing with the water of reservoir in the period of 4 days (EPA/5O5/2-90-001:1991). The safe concentration of studied wastewater is calculated by the equation

$$
S C=\frac{C C C}{T U_{c, \max } \cdot R P M F} \times 100 \%,
$$

where $T U_{\mathcal{c} \text {, max }}$ is the highest value of the units of toxicity $T U_{\mathcal{c}}, R M P F$ is the reasonable potential multiplying factor which depends on the coefficient of data variation, confidence level and probability. Coefficient of variation was calculated on the basis of standard deviation $\sigma$ and average value of chronic toxicity units $T U_{c, m}$ :

$$
C V=\frac{\sigma}{T U_{c, m}} .
$$

$R P M F$ was read for variation coefficient $C V=0.4$, confidence level $95 \%$ and probability of $95 \%$. CCC is accepted as $1 T U_{c}$.

All values of $L C(E C)_{50}$ as well as $S C$ value are expressed as volume percentage concentrations.

\subsection{Microcosm study}

Verification of calculated chronic safe concentration in microcosm study was conducted in 12 five-liter aquariums:

- 4 control aquariums,

- 4 aquariums containing safe concentration of the researched wastewater,

- 4 aquariums containing ten times higher than safe concentration of wastewater.

Each aquarium was filled with water treated in biofilter and settled by the following organisms: algae culture Desmodesmus quadricauda and Selenastrum capricornutum, duckweed Lemna minor, crustaceans Daphnia magna Straus. Model ecosystems with introduced organisms were subjected to weekly adaptation with aeration and light, and then appropriate concentrations of wastewater were added. Hydrobiological, microbiological and chemical parameters were assessed for analysis of ecosystems development dynamics during 4 weeks with 7-day intervals.

\subsubsection{Hydrobiological parameters}

Hydrobiological parameters included microscopic estimation of Daphnia magna Straus number using Kolkwitz's chamber, microscopic analysis of algae (Desmodesmus quadricauda and Selenastrum capricornutum) development, and assessment of leaves number of duckweed Lemna minor. Data are represented as cells/ml for algae and as units for crustaceans and duckweed development.

\subsubsection{Microbiological parameters}

Microbiological parameters included determination of total number of bacteria by Koch method by submerged seeding on nutrient agar medium (Grabińska-Łoniewska 1999). Results are represented as cfu/ml units.

\subsubsection{Chemical parameters}

Chemical parameters included $\mathrm{pH}$ determination by electrometric method, ammonia nitrogen determination by direct nesslerization method, nitrite and nitrate nitrogen determination by colorimetric method, dissolved orthophosphate determination by colorimetric method, chloride determination by titration method, chemical oxygen demand (COD) determination by dichromate reflux method (Clescerl et al. 1999). 


\section{Results and discussion}

The results of single-species toxicity tests on wastewater containing phenol are presented in Table 1.

Results of bioassays indicate harmful effects of wastewater containing phenol on all test organisms. $\mathrm{LC}(\mathrm{EC})_{50}$ values vary with regard to different test objects due to different sensitivity of organisms. The most sensible organism is Danio rerio, $\mathrm{LC}_{50}$ for which is $10.7 \%$. The most resistance organism is algae Desmodesmus quadricauda with $\mathrm{LC}_{50} 33.6 \%$. Toxicity assessment with regard to the acute toxicity on the basis of $\mathrm{TU}_{\mathrm{a}}$ values according to Persoon et al. (2003) was made on basis of data obtained from single-species bioassays. Researched wastewater is referred to III class of toxicity and shows acute toxicity.
Using LC(EC) $)_{50}$ values No Observed Effect Concentrations and chronic toxicity units $T U_{c}$ were obtained. $T U_{c}$ data were used for calculation of safe concentration of studied wastewater with regard to the chronic toxicity. Found safe concentration is $0.63 \%$ which corresponds to $0.63 \mathrm{mg}$ of phenol per liter.

The next stage of research consisted in microcosm study, where there were verified the safe concentration and the one 10 times higher than safe. Microcosm study shows effects of wastewater on organisms of different organizational levels as well as interactions among the different components resulting in indirect exposure effects of both functional and structural nature (Oskarsson et al. 2012).

Figures 1-4 present dynamics of microbiological and hydrobiological parameters during examination time in microcosm study.

Table 1. Results of single-species bioassays and toxicity assessment of wastewater

\begin{tabular}{|c|c|c|c|c|c|c|c|c|}
\hline No. & Test organism & Type of test & $\begin{array}{l}\text { Duration, } \\
\quad[\mathrm{h}]\end{array}$ & $\begin{array}{l}\mathrm{LC}(\mathrm{EC}) 50,[\%] \\
(95 \% \text { confi- } \\
\text { dence interval) }\end{array}$ & $T U_{a}$ & $\begin{array}{l}\text { Toxicity class } \\
\text { and assessment }\end{array}$ & NOEC & $T U_{c}$ \\
\hline 1 & $\begin{array}{l}\text { Desmodesmus } \\
\text { quadricauda }\end{array}$ & $\begin{array}{l}\text { growth inhibition } \\
\text { test }\end{array}$ & 72 & $\begin{array}{c}33.6 \\
(31.9-35.1)\end{array}$ & 2.98 & III, acute toxicity & 3.36 & 29.8 \\
\hline 2 & Vibrio fischeri & enzymatic tests & 0.5 & $\begin{array}{c}28.5 \\
(27.5-30.0)\end{array}$ & 3.51 & III, acute toxicity & 2.85 & 35.1 \\
\hline 3 & Lebistes reticulatus & Immobilization test & 96 & $\begin{array}{c}21.3 \\
(19.9-22.6)\end{array}$ & 4.69 & III, acute toxicity & 2.13 & 47 \\
\hline 4 & $\begin{array}{l}\text { Daphnia magna } \\
\text { Straus }\end{array}$ & survival test & 48 & $\begin{array}{c}19.6 \\
(18.4-20.8)\end{array}$ & 5.10 & III, acute toxicity & 1.96 & 51 \\
\hline 5 & $\begin{array}{l}\text { Daphnia magna } \\
\text { Straus }\end{array}$ & enzymatic test & 1 & $\begin{array}{c}19.6 \\
(18.2-20.6)\end{array}$ & 5.10 & III, acute toxicity & 1.96 & 51 \\
\hline 6 & Danio rerio & immobilization test & 96 & $\begin{array}{c}10.7 \\
(9.9-11.5)\end{array}$ & 9.35 & III, acute toxicity & 1.07 & 93.5 \\
\hline
\end{tabular}

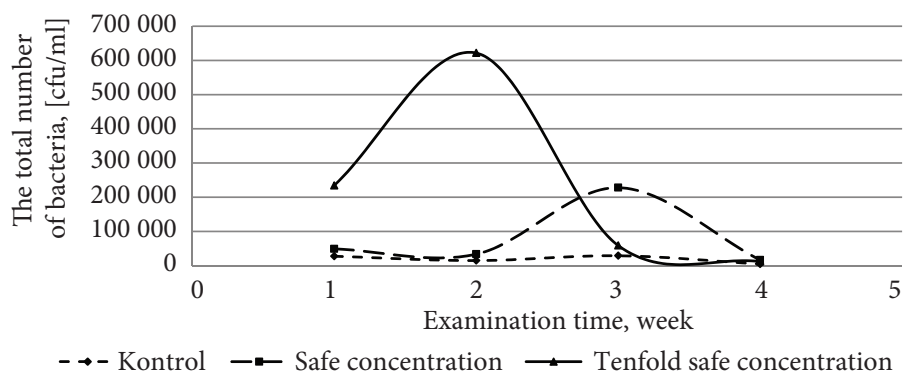

Figure 1. Dynamics of changes in the total number of bacteria in microcosm study

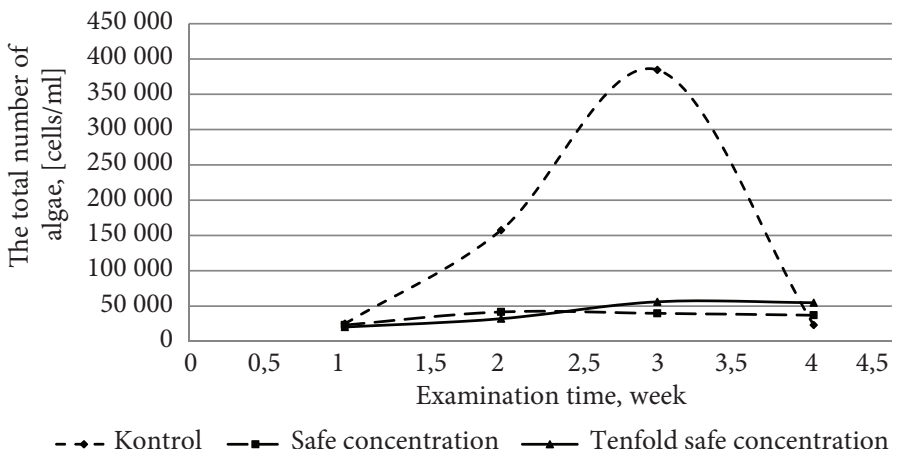

Figure 2. Dynamics of total number of algae development in microcosm study 


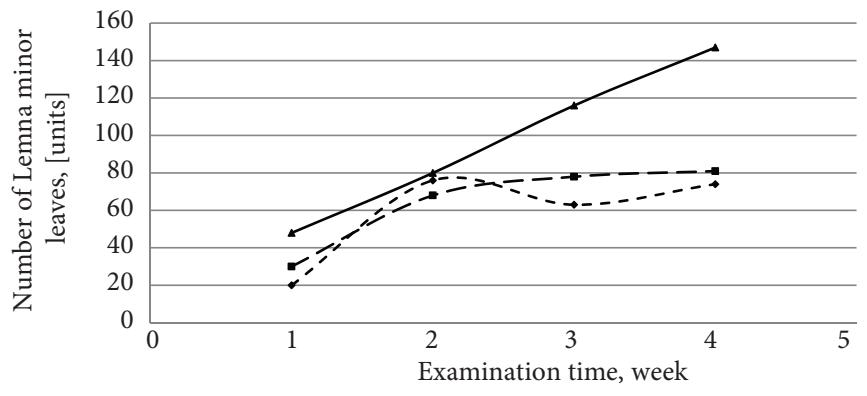

$\rightarrow$ Kontrol $\quad-$ Safe concentration $\longrightarrow$ Tenfold safe concentration

Figure 3. Dynamics of changing the leaves number of Lemna minor in microcosm study

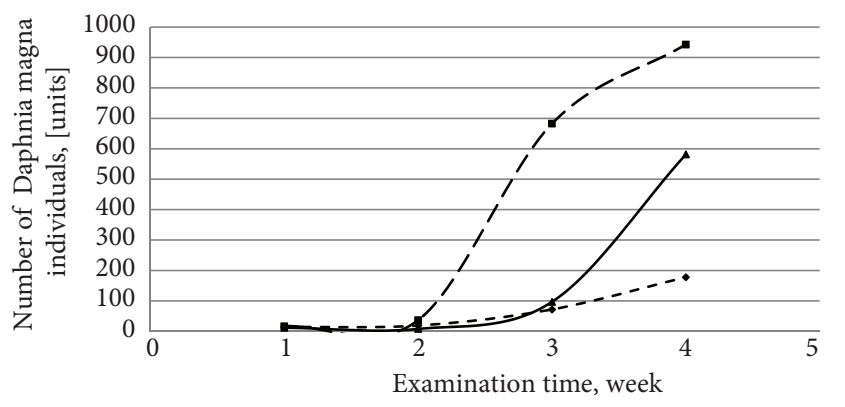

$\rightarrow$ Kontrol $\rightarrow-$ Safe concentration $\rightarrow$ Tenfold safe concentration

Figure 4. Dynamics of changing the number of Daphnia magna Straus in microcosm study

Changing of chemical parameters during examination time in microcosm study is presented in Table 2.

Table 2. Chemical parameters in microcosm study

\begin{tabular}{|c|c|c|c|c|}
\hline \multirow[b]{2}{*}{ Indicator } & \multirow{2}{*}{$\begin{array}{c}\text { Exami- } \\
\text { nation } \\
\text { time }\end{array}$} & \multicolumn{3}{|c|}{ Concentration } \\
\hline & & $\begin{array}{c}\text { Cont- } \\
\text { rol }\end{array}$ & $\begin{array}{c}\text { Safe } \\
\text { concen- } \\
\text { tration }\end{array}$ & $\begin{array}{c}\text { Tenfold safe } \\
\text { concen- } \\
\text { tration }\end{array}$ \\
\hline 1 & 2 & 3 & 4 & 5 \\
\hline \multirow{4}{*}{$\mathrm{pH}$} & Week 1 & 8.8 & 9.0 & 8.6 \\
\hline & Week 2 & 8.5 & 8.7 & 9.8 \\
\hline & Week 3 & 8.5 & 8.3 & 9.26 \\
\hline & Week 4 & 8.5 & 8.5 & 8.87 \\
\hline \multirow{4}{*}{$\begin{array}{l}\mathrm{COD}, \\
{\left[\frac{\mathrm{mg} \mathrm{O}_{2}}{\mathrm{dm}^{3}}\right]}\end{array}$} & Week 1 & 105.6 & 110.4 & 244.0 \\
\hline & Week 2 & 86.4 & 124.8 & 163.2 \\
\hline & Week 3 & 126.9 & 107.4 & 112.2 \\
\hline & Week 4 & 104.7 & 99.2 & 119.0 \\
\hline \multirow{4}{*}{$\begin{array}{l}\text { Ammonia } \\
\text { nitrogen } \mathrm{NH}_{4}^{+} \text {, } \\
{\left[\frac{\mathrm{mgN}-\mathrm{NH}_{4}^{+}}{\mathrm{dm}^{3}}\right]}\end{array}$} & Week 1 & 0.14 & 0.16 & 0.28 \\
\hline & Week 2 & 0.04 & 0.06 & 0.15 \\
\hline & Week 3 & 0.05 & 0.08 & 0.14 \\
\hline & Week 4 & 0.10 & 0.11 & 0.14 \\
\hline \multirow{4}{*}{$\begin{array}{l}\text { Nitrite nitrogen } \\
\mathrm{NO}_{2}^{-} \\
{\left[\frac{\mathrm{mgN}-\mathrm{NO}_{2}^{-}}{\mathrm{dm}^{3}}\right]}\end{array}$} & Week 1 & 0.023 & 0.050 & 0.050 \\
\hline & Week 2 & 0.005 & 0.007 & 0.007 \\
\hline & Week 3 & 0.004 & 0.006 & 0.006 \\
\hline & Week 4 & 0.011 & 0.050 & 0.006 \\
\hline
\end{tabular}

End of Table 2

\begin{tabular}{|c|c|c|c|c|}
\hline 1 & 2 & 3 & 4 & 5 \\
\hline \multirow{4}{*}{$\begin{array}{l}\text { Nitratenitrogen } \\
\mathrm{NO}_{3}^{--}, \\
{\left[\frac{\mathrm{mgN}^{-} \mathrm{NO}_{3}^{-}}{\mathrm{dm}^{3}}\right]}\end{array}$} & Week 1 & 1.3 & 1.1 & 1.0 \\
\hline & Week 2 & 1.2 & 1.1 & 0.9 \\
\hline & Week 3 & 0.9 & 1.0 & 1.2 \\
\hline & Week 4 & 1.1 & 1.2 & 1.0 \\
\hline \multirow{4}{*}{$\begin{array}{l}\text { Dissolved } \\
\text { orthophosphate } \\
\mathrm{PO}_{4}{ }^{3-} \text {, } \\
{\left[\frac{\mathrm{mgPO}_{4}{ }^{3-}}{\mathrm{dm}^{3}}\right]}\end{array}$} & Week 1 & 2.93 & 3.75 & 4.7 \\
\hline & Week 2 & 4.03 & 3.51 & 3.32 \\
\hline & Week 3 & 5.97 & 6.15 & 6.03 \\
\hline & Week 4 & 4.77 & 5.1 & 4.53 \\
\hline \multirow{4}{*}{$\begin{array}{l}\text { Chloride } \mathrm{Cl}^{-} \text {, } \\
{\left[\frac{\mathrm{mg} \mathrm{Cl}^{-}}{\mathrm{dm}^{3}}\right]}\end{array}$} & Week 1 & 211 & 210 & 228 \\
\hline & Week 2 & 248 & 246 & 269 \\
\hline & Week 3 & 275 & 270 & 285 \\
\hline & Week 4 & 280 & 286 & 308 \\
\hline
\end{tabular}

At the beginning of the experiment the population of bacteria in the sample with tenfold higher than safe concentration of wastewater is much greater than in other trials. This difference has developed in the period of a week adaptation of organisms to the environment independently of the added wastewater. Dynamics of bacteria population development in this sample is proportional to the availability of nutrients: at the second week bacterial growth is observed while concentrations of $\mathrm{NH}^{4+}, \mathrm{PO}^{3-}$, 
COD are decreased. It means that microorganisms consume carbon compounds, phosphorus and ammonium nitrogen to build biomass. At the $3^{\text {rd }}$ week decrease in the number of bacteria occurs after depletion of nutrients.

In microcosm with safe concentration of researched wastewater the amount of nutrients was less due to the smaller amount of introduced sewage, which was resulted in the less intense growth of microorganisms. The reason for bacteria number development in this sample between 2nd and 3rd week was the growth of crustacean Daphnia magna and increased amount of their wastes, which were the source of organic compounds for bacteria.

Growth of algae is observed in each sample, but most intensively it had been developed in the sample with tenfold higher than safe concentration of sewage. In the presence of such large amount of nutrients, there was an intensive growth of this algae population, reaching a maximum in the third week, and later their number began to decrease due to lack of nutrients. The same situation we observe in the sample with safe concentration of wastewater between $1^{\text {st }}$ and $2^{\text {nd }}$ week.

After observing the changes in algae and bacteria populations the toxic effects caused by wastewater containing phenol is not recognized. On the contrary, in the sample with sewage concentration tenfold higher than safe for most organisms we observe a significant stimulating effect of the added pollutant. It is most evident in the case of autotrophs.

Daphnia magna population increases with the enhancement of food availability (algae growth as well as nitrogen and phosphorus compounds).

Duckweed used for growth and reproduction contained in the environ-aqueous medium nitrogen and phosphorus.

Chloride ion concentration changes in a stable manner and it is not correlated with changes in populations and other chemicals. Increasing of chloride ions concentration indicates ongoing mineralization.

\section{Conclusions}

On the basis of single-species ecotoxicity tests results, it is determined that the synthetic sewage by Weinberger method with the addition of phenol showed acute toxicity in relation to all bio-indicators and belonged to the third toxicity class according to the criteria developed by Persoon et al. (2003).

Based on single species toxicity tests, chronic safe concentration of wastewater containing phenol $0.63 \%$, which corresponds to $0.63 \mathrm{mg} / \mathrm{l}$ of phenol, does not cause toxic effects in the test environment - microcosm.

Tenfold higher than safe concentration of wastewater caused a short-term effect of stimulation of organisms growth. After 4 weeks of research, the microbiological, most of chemical and some hydrobiological parameters have the tendency to approach to similar parameters measured in control. This indicates a self-purification of test ecosystems.
Safe concentration of phenol to aquatic ecosystems, calculated in accordance with Załęska-Radziwiłł extrapolation model, is $0.59 \mathrm{mg} / \mathrm{l}$, which differs slightly from data we have obtained for wastewater containing phenol (Załęska-Radziwiłł 1997). This indicates that the toxicity of the studied sewage to the aquatic ecosystems mainly caused by the presence of phenol and insignificantly depends on other components.

According to the regulatory documents in Ukraine, the maximum allowable concentration of phenol in surface water is $0.001 \mathrm{mg} / \mathrm{l}$ (Sanitary rules and regulations 1988). In EU countries, the maximum concentration of phenol allowed in drinking water is $0.0005 \mathrm{mg} / \mathrm{l}$ (Council Directive 98/83/EC). Concentration of phenol for all classes of surface water in Poland should not exceed $0.01 \mathrm{mg} / \mathrm{l}$ (Dz. U. 1482:2014). In all cases, the maximum allowable concentration of phenol in water bodies does not exceed determined safe concentration on the basis of single-species toxicity tests and verified in the microcosm study.

Scientific articles mainly focused on treatment of phenolic sewage, but there is a lack of such comprehensive ecotoxicological studies of wastewater, including singleand multi-species tests (Wiessner et al. 2014; Pishgar et al. 2014; Riauka et al. 2006; Mohammadi et al. 2015). The proposed research model can be used to determine and verify safe concentrations not only for wastewater with phenol, but also originating from other industrial sources, which may contribute greatly to the protection of aquatic ecosystems.

\section{Disclosure statement}

The research has been financed by the Department of Biology, Faculty of Building Services, Hydro and Environmental Engineering, Warsaw University of Technology. The terms of this arrangement have been reviewed and approved by the the aforementioned institution in accordance with its policy. The authors of this publication don't have any competing financial, professional, or personal interests from other parties.

\section{References}

Bazrafshan, E.; Mostafapour, F. K.; Mansourian, H. J. 2013. Phenolic compounds: health effects and its removal from aqueous environments by low cost adsorbents, Health Scope 2(2): 65-66.

https://doi.org/10.17795/jhealthscope-12993

Clescerl, L. S.; Greenberg, A. E.; Eaton, A. D. 1999. Standard methods for the examination of water and wastewater. $20^{\text {th }} \mathrm{ed}$. American Public Health Association/American Water Works Association/Water Environment Federation. Washington, District of Columbia.

Council Directive 98/83/EC of 3 November 1998 on the quality of water intended for human consumption [online], [cited 5 December 1998]. 23 p. Available from Internet: http://eur-lex.europa.eu/legal-content/EN/TXT/?uri=CELEX\%3A31998L0083

Dz. U. 1482:2014. Rozporzadzenie Ministra Środowiska $z$ dnia 22 października 2014 r. w sprawie sposobu klasyfikacji stanu 
jednolitych części wód powierzchniowych oraz środowiskowych norm jakości dla substancji priorytetowych. Dziennik Ustaw 2014 r. poz. 1482.

EPA/5O5/2-90-001:1991. Technical support Document for Water Quality-Based Toxics Control. Office of Water, United States Environmental protection Agency. Washington, District of Columbia.

Gao, H.; Zhang, S. H.; Xiong, D. Q.; Liu, N.; Gong, W. M.; Wang, Q. 2006. Study on acute toxicities of phenol and aniline to two marine organisms, Marine Environmental Science 25: 33-36.

Grabińska-Łoniewska, A. 1999. Ćwiczenia laboratoryjne z mikrobiologii ogólnej. Oficyna Wydawnicza Politechniki Warszawskiej.

Hansch, C.; McCarns, S.; Smith, C.; Dodittle, D. 2000. Comparative Quantitative Structure-Activity Relationship evidence for a free-radical mechanism of phenol-induced toxicity, Chemico-Biological Interactions 127(1): 61-72. https://doi.org/10.1016/S0009-2797(00)00171-X

Hori, T. S. F.; Avilez, I. M.; Inoue, L. K.; Moraes, G. 2006. Metabolical changes induced by chronic phenol exposure in matrinxã Brycon cephalus (Teleostei: Characidae) juveniles, Comparative Biochemistry and Physiology C 143: 67-72. https://doi.org/10.1016/j.cbpc.2005.12.004

Huang, D. S.; Tseng, I. C.; Liou, H. Y.; Huang, C. M. 1996. acute toxicity of cresols to pseudomonas - an initial oxygen-uptake method, Journal of the Chinese Chemical Society 43(5): 439-443. https://doi.org/10.1002/jccs.199600063

ISO 6341:2012(E). Water quality - Determination of the inhibition of the mobility of Daphnia magna Straus (Cladocera, Crustacea) - Acute toxicity test.

ISO 8692:2012(E). Water quality - Fresh water algal growth inhibition test with unicellular green algae.

Janssen, C. R.; Espiritu E. Q.; Persoone, G. 1993. Evaluation of the new "Enzymatic Inhibition" criterion for rapid toxicity testing with Daphnia magna, in A. M. V. M. Soares, P. Calow (Eds.). Progress in standardization of aquatic toxicity tests. London: Lewis Publishers, 71-81.

Kaiser, K. L.; Palabrica, V. S. 1991. Photobacterium phosphoreum Toxicity Data Index, Water Pollution Research Journal of Canada 26(3): 361-431.

LUMIStox. 1994. Bedienungsanleitung manual. Dr Lange Corporation, Dusseldorf.

Michalowicz, J.; Duda, W. 2007. Phenols-sources and toxicity, Polish Journal of Environmental Studies 16(3): 347-362.

Mohammadi, S.; Kargari, A.; Sanaeepur, H.; Abbassian, K.; Najafi, A.; Mofarrah, E. 2015. Phenol removal from industrial wastewaters: a short review, Desalination and Water Treatment 53(8): 2215-2234.

https://doi.org/10.1080/19443994.2014.883327

Moraes, F. D.; Figueiredo, J. S. L.; Rossi, P. A.; Venturini, F. P.; Moraes, G. 2015. Acute toxicity and sublethal effects of phenol on hematological parameters of channel catfish Ictalurus punctatus and pacu Piaractus mesopotamicus, Ecotoxicology and Environmental Contamination 10(1): 31-36.

https://doi.org/10.5132/eec.2015.01.05

Nahed S. Gad; Amal S. Saad. 2008. Effect of environmental pollution by phenol on some physiological parameters of Oreochromis niloticus, Global Veterinaria 2(6): 312-319.

Oskarsson, H.; Wiklund, A. K. E.; Thorsén, G.; Danielsson, G.; Kumblad, L. 2014. community interactions modify the effects of pharmaceutical exposure: a microcosm study on responses to propranolol in Baltic Sea coastal organisms, Public Library of Science One 9(4), e93774.

https://doi.org/10.1371/journal.pone.0093774
Park, J.-S.; Brown, M. T.; Han, T. 2012. Phenol toxicity to the aquatic macrophyte Lemna paucicostata, Aquatic Toxicology 106: $182-188$.

https://doi.org/10.1016/j.aquatox.2011.10.004

Persoon, G.; Marsalek, B.; Blinova, I.; Törökne, A.; Zarina, D.; Manusadzianas, L.; Nałęcz-Jawecki, G.; Tofan, L.; Stephanova, N.; Tothova, L.; Kolar, B. 2003. Praktyczna i prosta klasyfikacja poziomu toksyczności wód pitnych i ścieków przy użyciu systemów Microbiotest, Environmental Toxicology 18: 395-402.

Pishgar, P.; Najafpour, G. D.; Neya, B. N.; Mousavi, N.; Bakhshi, Z. 2014. Effects of organic loading rate and hydraulic retention time on treatment of phenolic wastewater in an anaerobic immobilized fluidized bed reactor, Journal of Environmental Engineering and Landscape Management 22(1): 40-49. https://doi.org/10.3846/16486897.2013.800079

PN-90/C-04610.04:1990. Woda i ścieki. Badania toksyczności zanieczyszczeń dla organizmów wodnych. Oznaczanie toksyczności ostrej na gupiku Lebistes reticulatus Peters [Water and wastewater. Test for toxicity of pollutants to aquatic organisms. Determination of acute toxicity to Lebistes reticulatus Peters]. Polish Standard.

Provisional List. 1993. Acute Lethal (Effective) Concentration 50's of freshwater toxkits Versus D. Magna and Microtox for a number of inorganic, organic and pharmaceutical compounds. Provisional List - 03/06/93. Materials of the University of Gent.

Riauka, A.; Žemaitaitis, A.; Klimavičiūtè, R.; Skrebiškienè, R.; Ramenyt, R. 2006. Purification and reuse of coloured textile wastewater, Journal of Environmental Engineering and Landscape Management 14(1): 37-45.

Saha, N. C.; Bhunia, F.; Kaviraj, A. 1999. Toxicity of phenol to fish and aquatic ecosystems, Bulletin of Environmental Contamination and Toxicology 63(2): 195-202. https://doi.org/10.1007/s001289900966

SanPiN 4630-88:1988. Sanitamye pravila i notrmy ohrany poverkhnostnyh vod ot zagryazneniya [Sanitary rules and standards for protection of surface water from pollution]. Ukrainian Standard.

Sheedy, B. R.; Lazorchak, J. M.; Grunwald, D. J.; Pickering, Q. H.; Pilli, A.; Hall, D.; Weeb, R. 1991. Effects of pollution on freshwater organisms, Journal of the Water Pollution Control Federation 63: 619-696.

Tisler, T.; Zagorc-Koncan, J. 1997. Comparative assessment of toxicity of phenol, formaldehyde, and industrial wastewater to aquatic organisms, Water, Air, and Soil Pollution 97(3): 315-322. https://doi.org/10.1007/BF02407469

Weber, E. 1972. Grundriss der biologischen Statistik für Naturwissenschaftler, Landwirte und Mediziner. VEB Gustav Fischer, Jena, Germany. 674 p.

Weinberger, L.W. 1949. Nitrogen metabolism in the activated sludge process: $\mathrm{ScD}$ thesis. Massachusetts Institute of Technology. Cambridge, Massachusetts.

Wiessner, A.; Müller, J. A.; Kuschk, P.; Kappelmeyer, U.; Kästner, M.; Liu, Y. J.; Stottmeister, U. 2014. Environmental pollution by wastewater from brown coal processing - a remediation case study in Germany, Journal of Environmental Engineering and Landscape Management 22(1): 71-83. https://doi.org/10.3846/16486897.2013.808640

Zaki, M. S.; Fawzi, O. M.; Shalaby, S. I. 2011. Phenol toxicity affecting hematological changes in catfish (Clarius lazera), Life Science Journal 8(2): 244-248.

Załęska-Radziwiłł, M. 1997. System wyznaczania stężeń bezpiecznych zanieczyszczeń dla biocenoz wodnych na podstawie badań toksykologicznych: Praca doktorska. Politechnika Warszawska. 